\title{
Positive-Strand RNA Viruses Infecting the Red Imported Fire Ant, Solenopsis invicta
}

\author{
Steven M. Valles \\ USDA-ARS, Center for Medical, Agricultural and Veterinary Entomology, 1600 SW 23rd Drive, Gainesville, FL 32608, USA
}

Correspondence should be addressed to Steven M. Valles, steven.valles@ars.usda.gov

Received 6 June 2011; Accepted 15 August 2011

Academic Editor: Alain Lenoir

Copyright () 2012 Steven M. Valles. This is an open access article distributed under the Creative Commons Attribution License, which permits unrestricted use, distribution, and reproduction in any medium, provided the original work is properly cited.

The imported fire ants, Solenopsis invicta and S. richteri were introduced into the USA between 1918 and 1945. Since that time, they have expanded their USA range to include some 138 million hectares. Their introduction has had significant economic consequences with costs associated with damage and control efforts estimated at 6 billion dollars annually in the USA. The general consensus of entomologists and myrmecologists is that permanent, sustainable control of these ants in the USA will likely depend on self-sustaining biological control agents. A metagenomics approach successfully resulted in discovery of three viruses infecting S. invicta. Solenopsis invicta virus 1 (SINV-1), SINV-2, and SINV-3 are all positive, single-stranded RNA viruses and represent the first viral discoveries in any ant species. Molecular characterization, host relationships, and potential development and use of SINV-1, SINV-2, and SINV-3 as biopesticides are discussed.

\section{Introduction}

The black imported fire ant (Solenopsis richteri) and red imported fire ant (S. invicta) were thought to have been introduced into the United States in 1918 [1] and sometime between 1933 and 1945 [2], respectively. S. invicta has clearly emerged as the most successful of the two ant species, largely displacing and relegating $S$. richteri to a roughly contiguous area in eastern Mississippi, western Alabama, and western Tennessee [2]. In contrast, since its introduction, S. invicta has expanded its range to infest more than 138 million hectares (Figure 1) from Virginia, south to Florida, and west to California [3]. Although both of these fire ant species are invasive, $S$. invicta is by far the most successful and considered the major pest species in the USA. Thus, in the strictest sense, the term "imported fire ants" (in the USA) refers to both S. invicta and S. richteri. However, in reality, efforts to study, understand, and control imported fire ants are focused nearly completely on S. invicta.

Introduction of these ants into the USA has had significant economic consequences. Damage attributed to $S$. invicta is quite diverse, including, physical damage to agricultural commodities, livestock, and equipment, infrastructure (e.g., roads and electrical equipment), negatively impacting biological diversity, and even human health [4]. Costs associated with damage and control efforts are estimated to cost 6 billion dollars annually in the USA [5]. Although a number of highly effective insecticides are available to control S. invicta and $S$. richteri, they must be used regularly to provide sustained control. If insecticide use is discontinued, fire ant populations invariably re-inhabit these previously treated areas. In addition, because fire ants are so ubiquitous within the infested region, insecticide-based control is impractical, from both environmental and economic standpoints.

A number of comparative ecological studies have demonstrated that S. invicta nest density, nest volume, and population density compared with other ant species in the community are significantly greater in the USA compared with South America where the ant is native $[6,7]$. These differences have been attributed to a lack of natural enemies in the USA as a result of a bottleneck event at the time of introduction [7]. The enemy release hypothesis [8] states that introduced species arrive without their complement of natural enemies, and release from these organisms confers 


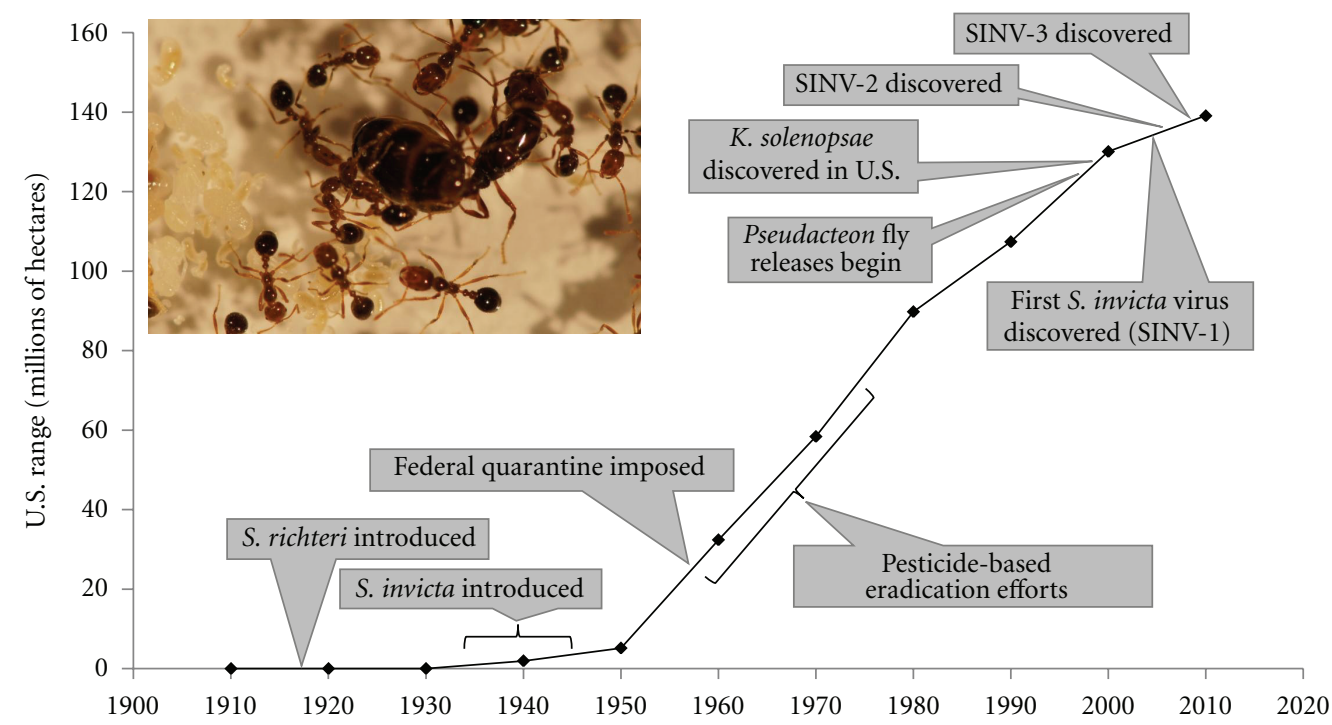

Figure 1: Seminal events during the invasion of Solenopsis invicta and S. richteri in relation to their USA quarantined range. Since the introduction of S. invicta and S. richteri into the USA, efforts to contain and eradicate the ants have been attempted [2, 4]. The USA federal government emplaced a quarantine in May 1958 to limit the rate of range expansion of the ants. This quarantine is still enforced by the Animal and Plant Health Inspection Service (APHIS) today and prohibits movement of soil-containing products (e.g., sod, nursery stock, sand, etc.) or soil-moving equipment from a quarantined to a non-quarantined area unless first treated in an APHIS-specified manner to kill fire ants. The range values correspond to areas quarantined and do not relate changing population densities in the USA. Rather, the graph illustrates the expanding geographic range of these ants. Eradication efforts were attempted from 1957 through 1978 using several organochlorine insecticides (heptachlor, dieldrin, and mirex). Research efforts to discover, develop, and release pathogens and parasites as control agents in the USA resulted in identification and/or release of a microsporidian pathogen (Kneallhazia solenopsae) [18], viruses [2426], and Pseudacteon parasites [28]. Inset: S. invicta queen surrounded by workers and brood. Quarantine data were provided by APHIS [3] and the figure was adapted from Lofgren [29].

superior performance and attainment of higher densities in the introduced region [9]. The S. invicta introduction into the USA exemplifies this hypothesis; at least 30 fire ant natural enemies have been identified in South America, but nearly all of these are absent among USA populations [7, 10-14]. Indeed, this premise has served as the impetus for research based on discovery, development, and use of pathogens and parasites because permanent, sustainable control of S. invicta across its USA range will likely depend on self-sustaining biological control agents as part of an integrated management strategy.

A limited number of pathogens and parasites of S. invicta have been detected or intentionally released in the USA. Currently, 2 species of endoparasitic fungi $[15,16]$, a microsporidian obligate parasite $[17,18]$, a neogregarine parasite $[19$, 20], a strepsipteran parasite [21], phorid flies in the genus Pseudacteon [22, 23], and 3 RNA viruses [24-26] comprise the known self-sustaining, biological control agents found in North American S. invicta. Discovery and exploitation of additional biological control agents, from either South or North American populations, could aid the control and suppression of fire ants and remain a key research topic for a number of academic and government laboratories [10]. Indeed, the number of natural enemies found in recently introduced S. invicta populations in Australia and China are even fewer than in the USA [27].

\section{Virus Discovery}

Although viruses can be important biological control agents against pest insect populations [30], until recently, no viruses had been shown to infect $S$. invicta. Indeed, no virus had been reported in any species of the Formicidae before the discovery of the fire ant virus, SINV-1. Extensive searches for pathogens, including viruses, of S. invicta have been conducted in the introduced (USA) and native (South America) ranges using traditional methods (identification of unhealthy ants followed by microscopic examination or simply examination of large numbers of healthy fire ant colonies) [1114]. However, with the exception of "virus-like particles" observed in an unidentified species of Solenopsis from Brazil [31], no viruses had been described by these methods. Further complicating discovery of pathogens in fire ants by traditional methods is their fastidious nature [32]; sick or dying colony members are promptly removed from the nest precluding detection.

In an effort to identify virus infections of S. invicta, a metagenomics approach was employed [33]. The primary intention of this analysis was to utilize homologous gene identity to facilitate discovery of viruses infecting S. invicta that could potentially be used in pest management. A non-normalized gene expression library was created from a monogyne colony of $S$. invicta and a relatively small number $(2,304)$ of clones 


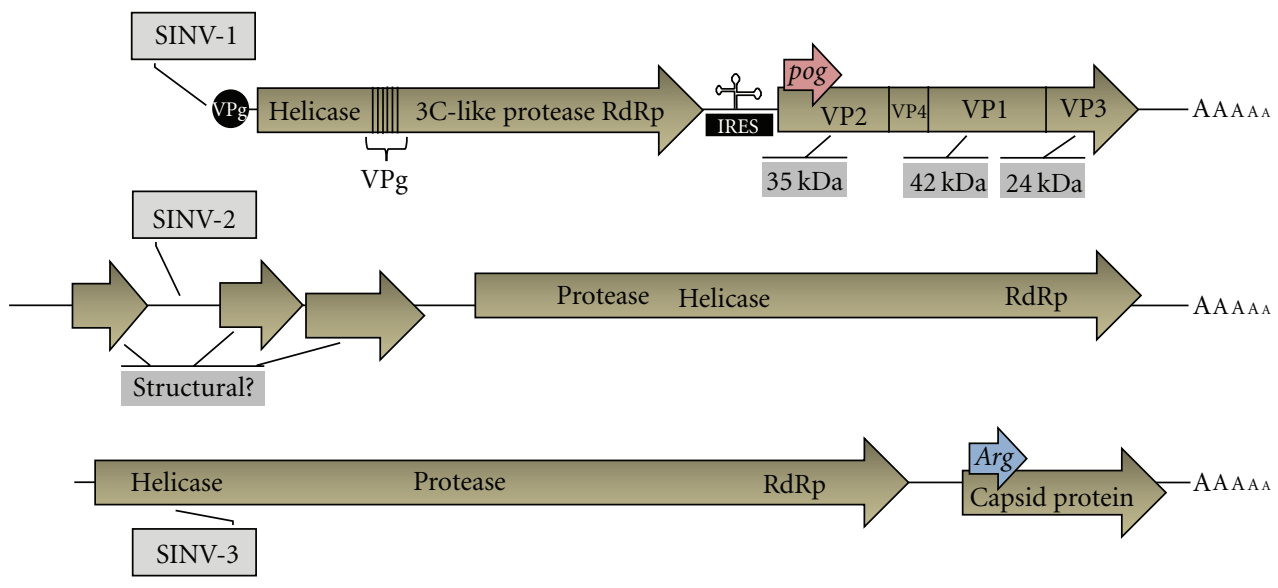

FIGURE 2: Comparative genome architecture of SINV-1, SINV-2, and SINV-3. Orientation of each genome is $5^{\prime}$ to $3^{\prime}$ (left to right). Relative positions of non-structural and structural proteins are indicated within each open reading frame (rectangles). ORFs are illustrated in different vertical positions to show their in-frame, comparative relationships. The SINV-1 genome is monopartite, dicistronic, and possesses 6 copies of the viral protein genome (VPg) peptide, an intergenic IRES, a predicted overlapping gene (pog) within ORF 2, and wellcharacterized capsid proteins (VPs) of known mass. The SINV-2 genome is monopartite with non-structural proteins encoded by the $3^{\prime}$ proximal ORF. The 3 small ORFs at the $5^{\prime}$-proximal end of the genome are presumed capsid proteins. The SINV-3 genome is monopartite with non-structural proteins encoded by ORF 1 ( $5^{\prime}$-proximal) and capsid proteins by ORF 2 ( $3^{\prime}$-proximal). An overlapping ORF (Arg) was identified within ORF 2 of a virus isolate from infected S. invicta ants from Argentina.

were sequenced. After assembly, 1,054 unique sequences were yielded and deposited into the GenBank database (accession numbers EH412746 through EH413799). Six sequences exhibited significant identity with RNA viruses. Subsequent analysis of these expressed sequence tags led to the discovery of three, positive, single-stranded RNA viruses, Solenopsis invicta virus 1 (SINV-1), SINV-2, and SINV-3 [24-26].

\section{Solenopsis invicta Virus 1}

3.1. Genome Characterization. SINV-1, the first virus discovered in S. invicta, is the best characterized of the three currently described fire ant viruses [25]. Acquisition of the SINV-1 genome sequence was completed by a series of $5^{\prime}$ and $3^{\prime}$ rapid amplification of cDNA ends (RACE) reactions using expressed sequence tags identified from an expression library as anchor templates. The $\mathrm{A} / \mathrm{T}$ rich genome is composed of 8,026 nucleotides excluding the poly(A) tail found on the $3^{\prime}$ end (Genbank accession AY634314). Analysis of the genome (Figure 2) revealed 2 large open reading frames (ORFs) in the sense orientation (within frame) with an untranslated region (UTR) at each end and between the two ORFs. BLAST analysis [34] of ORFs 1 ( $5^{\prime}$-proximal) and $2\left(3^{\prime}-\right.$ proximal) revealed identity to nonstructural and structural proteins, respectively, from positive, single-stranded RNA viruses. ORF 1 was found to exhibit a characteristic helicase, protease, and RNA-dependent RNA polymerase (RdRp) cassette ascribed to viruses in the Picornavirales [35] and ORF 2 the structural, or viral capsid, proteins. No large ORFs were found in the inverse orientation suggesting that the SINV-1 genome is a positive, single-stranded RNA virus. The $5^{\prime}, 3^{\prime}$, and intergenic UTRs were comprised of 27,223 , and 204 nucleotides, respectively.
ORF 1 commenced at the first start AUG codon present at nucleotide position 28 and ended at the UAA stop codon at nucleotide 4,218 which encoded a predicted product of 1,397 amino acids with a molecular mass of $160,327 \mathrm{Da}$. ORF 1 conspicuously lacks a region thought to suppress host antiviral responses at the N-terminus-a characteristic exhibited by other dicistroviruses [36-38]. Thus, Nakashima and Shibuya [39] have suggested that SINV-1 lacks approximately 1,500 nucleotides at the $5^{\prime}$ end of the genome. However, no empirical evidence for this suggestion has been reported. Sequence similarity analyses of ORF 1 identified domains consistent with a helicase, protease, and $\mathrm{RdRp}$ (Figure 2) [25]. Nakashima and Shibuya [39] identified the putative viral protein genome $(\mathrm{VPg})$ sequence and location in SINV-1 ORF 1. The VPg is a peptide covalently linked at the $5^{\prime}$ terminus of picornavirus genomes and serves as a primer for viral RNA genome replication [40]. Six copies of the heterologous 18 amino acid VPg peptide were identified between the helicase and 3C-like protease of SINV1 ORF 1 (Figure 2), the most for any dicistrovirus [39]. Multiple VPg copies are thought to facilitate multiplication of dicistroviruses because fewer translation cycles of the nonstructural polyprotein (ORF 1 for SINV-1) are necessary for viral replication to occur compared with the intergenic internal ribosome entry site-mediated production of the structural polyprotein (ORF 2). The $2 \mathrm{C} / 3 \mathrm{~A}$ and $3 \mathrm{C} / 3 \mathrm{D}$ cleavage site positions were predicted within ORF 1 of SINV-1 [41].

ORF 2 was originally reported [25] to commence at nucleotide position 4,390 (canonical AUG start codon), however, it was later revealed empirically to actually start at codon GCU (genome position 4423-4425) encoding an alanine [42]. ORF 2 initiation at this noncanonical codon is a consistent characteristic of dicistroviruses [43] and its presence and location were predicted to occur in SINV-1 [44] 


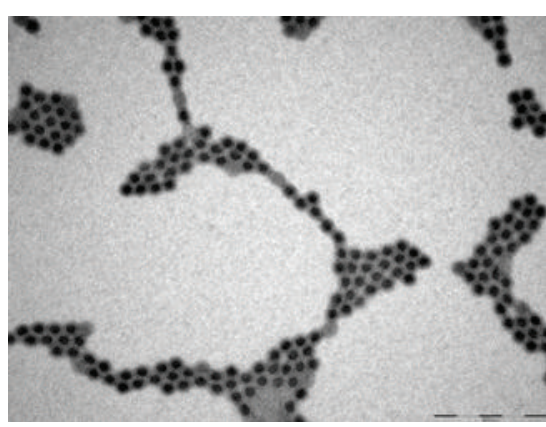

(a)

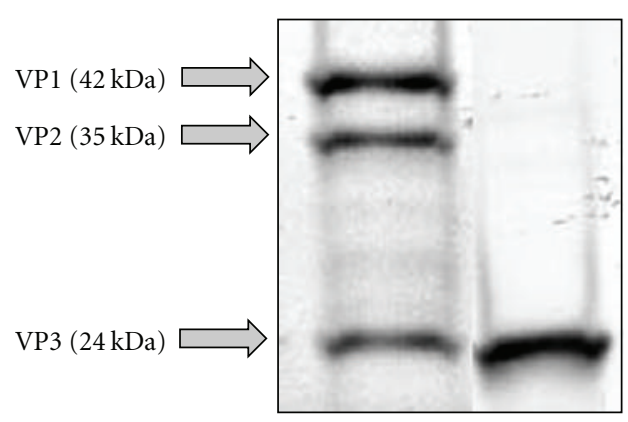

(b)

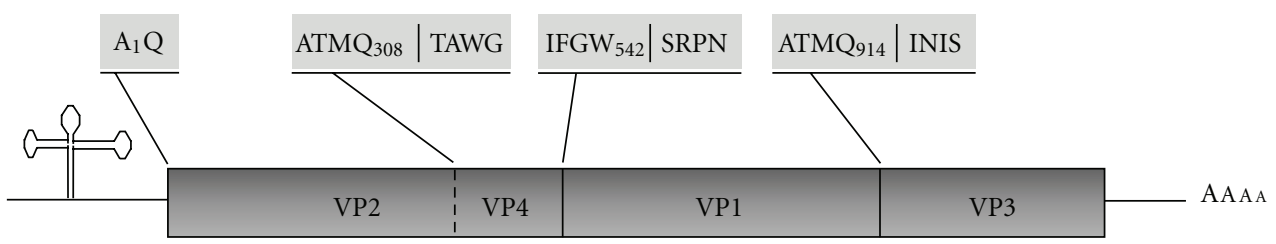

(c)

Figure 3: (a) Electron micrograph of purified SINV-1 particles. Scale bar represents $200 \mathrm{~nm}$. (b) SINV-1 capsid proteins separated by SDS-PAGE (lane 1) and probed with polyclonal antibodies developed toward a portion of the predicted capsid protein, VP3 (lane 2). (c) Illustration of the intergenic region, IRES, and ORF 2 of SINV-1. Scissile bonds of each capsid protein of ORF 2 as determined by N-terminal sequence analysis of VP1, VP2, and VP3. Cleavage positions (subscript numeral) and amino acid residues about the cleavage site (vertical line) are illustrated.

before being empirically determined [42]. Thus, ORF 2 is comprised of 1,126 amino acids with a molecular mass of $126,434 \mathrm{Da}$. SDS-PAGE analysis of purified SINV-1 particles yielded 3 major and one minor protein band (Figure 3 ). The capsid proteins were labeled VP1, VP2, VP3, and VP4 based on mass and $\mathrm{N}$-terminal sequence analysis of each of these proteins identified their respective positions within ORF 2 (Figures 2 and 3). Western analysis conducted with polyclonal antibodies developed from a peptide synthesized from the predicted amino acid sequence of VP3 (SRGGYRYKFFADDN) confirmed its location and synthesis from ORF 2 (Figure 3). The empirically determined and predicted molecular mass of VP0 (VP2 + VP4) $(60.6 \mathrm{kDa})$, VP1 $(41.8 \mathrm{kDa})$, and VP3 $(24.0 \mathrm{kDa})$ were in agreement [42]. The positional organization of the capsid proteins of SINV-1 ORF 2 did not follow the pattern exhibited by most known dicistroviruses when based on mass (i.e., $\mathrm{NH}_{2}$-VP2-VP4VP3-VP1). Although VP0 (VP2 + VP4) was at the N-terminus of ORF 2, and VP1 and VP3 were downstream of VP0, VP1 was found between VP0 and VP3. This organization $\left(\mathrm{NH}_{2}\right.$-VP2-VP4-VP1-VP3) was also reported for deformed wing virus (DWV), an iflavirus [45]; SINV-1 and DWV both possess an unusually large VP1. The scissile bonds for VP0/VP1 and VP1/VP3 were located at amino acid positions 542/543 and 914/915, respectively. Amino acid residues at these junctions were consistent with other dicistroviruses and unclassified picorna-like insect-infecting viruses [46]. Amino acid residues $\mathrm{G}_{541}, \mathrm{~S}_{543}$, and $\mathrm{P}_{545}$ at the VP4/VP1 cleavage site and $\mathrm{Q}_{914}$ at the VP1/VP3 cleavage site were conserved. These sites exhibited highest identities with Kashmir bee virus (KBV), Acute bee paralysis virus (ABPV), and Israeli acute paralysis virus (IAPV), all of which infect honey bees $[47,48]$.

A third overlapping ORF of unknown function has been identified at the $5^{\prime}$ end of SINV-1 ORF 2 in the +1 reading frame (Figure 2) [49]. The gene has been provisionally named predicted overlapping gene (pog). Protein motif searches of pog revealed weak relationships precluding assignment of a potential function. Interestingly, all hymenopteran-infecting dicistroviruses in the Aparavirus genus (KBV, ABPV, SINV-1 and IAPV) feature the pog gene. However, neither a transcript nor protein encoded by pog has been detected.

The $5^{\prime}$ and intergenic UTRs of dicistroviruses characteristically contain IRES regions that direct translation independent of a 7-methyl guanosine cap [50, 51]. SINV-1 has been shown to possess a Type II intergenic IRES based on sequence, structure, and homology within the dicistroviruses $[44,52]$. Hertz and Thompson [53] have demonstrated that the SINV-1 IGR IRES is translation competent in yeast and mammalian cells.

Although positive, single-stranded RNA viruses, like SINV-1, do not synthesize a DNA template during any portion of their life cycle, portions of some positive, singlestranded RNA virus genomes (including a dicistrovirus) have been reported to be integrated into their host genomes. Interestingly, these integration events apparently afforded protection to the host from infection by the corresponding virus [54-56]. Because SINV-1 may be exploited as a microbial control agent, it was important to determine whether integration of a portion of the virus genome occurred in the host. A series of oligonucleotide primer pairs covering the entire 
genome of SINV-1 were used to probe the genome of its host for integrated fragments of the viral genome [57]. Among 32 $S$. invicta genomic DNA samples collected from Argentina and the USA, no SINV-1 genome integration was detected.

3.2. Host Specificity and Prevalence. SINV-1 has been shown to infect $S$. invicta in the USA and Argentina [58-61]. Monogyne and polygyne S. invicta colonies [62] serve as hosts for SINV-1 [63]. However, SINV-1 infections appear to be more prevalent among polygyne $S$. invicta colonies [64]. S. geminata, S. richteri, the S. invicta/S. richteri hybrid, the S. geminata/S. xyloni hybrid (SMV unpublished) and $S$. carolinensis were also found to be infected with SINV-1 [58]. The infections in Solenopsis species other than S. invicta appear to be limited to areas in which $S$. invicta is sympatric and well established. SINV-1 was not detected in S. xyloni nor was it detected in S. geminata from southern Mexico (where S. invicta is not found currently), Hawaii, or Australia (SMV unpublished). Although still developing, these data suggest that S. invicta is the primary host of SINV-1 with other species in the Solenopsis genus serving as hosts occasionally (acquired from sympatric, SINV-1-infected S. invicta).

SINV-1 was distributed widely among $S$. invicta populations throughout the USA and Argentina $[58,60]$ with intercolony infection rates ranging from $<10 \%$ [58] to $>90 \%$ [63]. SINV-1 was detected in fire ants collected from all USA states examined with the exception of New Mexico. Although some dicistroviruses, like Cricket paralysis virus (CrPV), exhibit extremely wide host ranges, others, like Drosophila $\mathrm{C}$ virus (DCV), exhibit a genus-limited host range as observed for SINV-1 [50, 51, 65].

A strong relationship between temperature and SINV1 colony prevalence was reported in two separate studies $[58,63]$. Thus, time of collection (as it relates to temperature) must be considered when evaluating comparative prevalence data for SINV-1. This temperature dependency may be the result of more efficient IGR IRES activity. Hertz and Thompson [53] have shown recently that the SINV-1 IGR IRES exhibits increased activity at higher temperatures (3 to 5-fold). Further, the temperature-dependent enhanced activity resided in the ribosome binding domain of the IRES $[53,66]$. So, the seasonally observed prevalence of SINV-1 appears directly related to the ability of the virus to replicate more efficiently at higher temperatures and not necessarily influenced by the behavior of the ant host.

Multiple genotypes of SINV-1 have been identified [25, $67,68]$, and genomic diversity has been attributed to a high mutation rate characteristic of positive, single-stranded RNA viruses [69, 70]. Phylogenetic analysis of nucleotide sequences from the structural protein regions of the SINV-1 genome indicated divergence between isolates infecting North American and South American S. invicta [58] suggesting a prolonged duration of separation on the two continents. The analysis also indicated that North American SINV-1 had diverged more recently compared with those from Argentina. Indeed, a more extensive examination of the conserved RdRp region of the SINV-1 genome from Solenopsis hosts across the USA and northern Argentina revealed clustering of Argentinean sequences, distinct from the USA sequences [59]. Thus, SINV-1 in North America likely arrived with one of the founding introductions of S. invicta from South America. This conclusion is supported by the lack of infection among other Solenopsis species (S. geminata and $S$. xyloni) in areas devoid (Mexico and Hawaii) or with incipient infestations of S. invicta (New Mexico, California, and Australia). SINV-1 infection of S. geminata and S. carolinensis (in Florida and Northern Mexico/Southern Texas) may have originated from introduced S. invicta or S. richteri.

SINV-1 was capable of being detected retrospectively in alcohol-stored arthropods for at least 2 years facilitating host specificity evaluations [71]. Pitfall collections of 1,523 ants from 16 genera (excluding Solenopsis) tested negative for SINV-1 from areas in Florida where SINV-1 was present in the S. invicta community [58]. Likewise, 282 other arthropods in four classes and ten families within the Hexapoda were negative for SINV-1. Even Pseudacteon parasitoids that complete development within S. invicta do not serve as hosts of SINV-1 [72]. Thus, SINV-1 appears limited to the Solenopsis genus with $S$. invicta likely the primary host.

3.3. Stage and Tissue Tropism, Transmission. Real-time PCR was employed to determine the presence of SINV-1 in tissues, individual ants, and among colonies of $S$. invicta by quantifying the genome of the virus $[73,74]$. Initial experiments examined groups of tissues collectively to pinpoint the location of the virus infection. In workers, the abdomen contained the highest proportion of SINV-1; virus was also detected in the head and thorax of worker ants, but at very low rates (Figure 4). Among the remaining abdominal tissue groups, SINV-1 was detected occasionally in worker Malpighian tubules, the poison sac, hindgut and crop, but the greatest concentration of SINV-1 was in the midgut. Larval infection was also largely limited to the alimentary canal (Figure 4). SINV-1 specificity for the midgut of S. invicta is consistent with a number of other insect-infecting positive, single-stranded RNA viruses. Ingestion and the alimentary canal feature prominently in dicistrovirus infection acquisition and transmission processes [75]. Indeed, among the 14 described dicistroviruses, 12 exhibit a tissue tropism toward some part of the alimentary canal of their hosts [76]. Also, the gut contents of many hosts have been shown to contain high numbers of viral particles (e.g., Himetobi $\mathrm{P}$ virus (HiPV) [77], SINV-1 [73], DCV [78], and Triatoma virus $(\mathrm{TrV})[79,80])$.

Electron microscopy of worker and larval gut homogenates revealed the presence of spherical virus particles with a diameter of 30-35 nm, consistent with SINV-1. The molecular and microscopic data suggest that SINV-1 replicates in gut epithelial cells of $S$. invicta and infectious viral particles are shed into the gut lumen $[76,81]$. From there, the particles may be passed to nestmates by trophallaxis or substrate contamination by defecation [81]. Large quantities of SINV1 detected in the gut contents of $S$. invicta larvae [73] suggest that this stage facilitates intra-colony dissemination of SINV1. Late-instar S. invicta larvae digest all solid food for the colony which is redistributed in liquid form to nestmates 

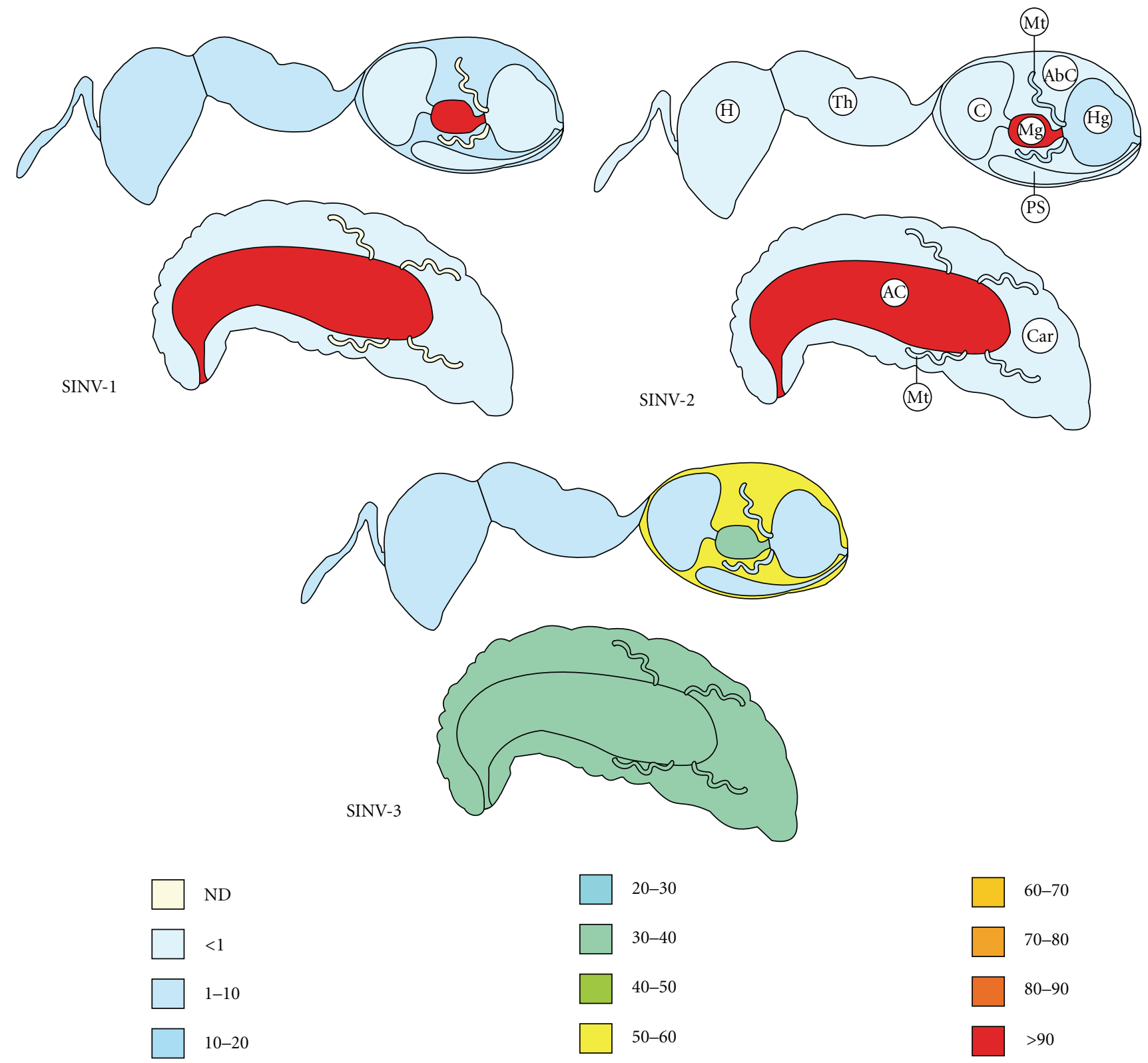

FIgURE 4: Tissue tropism of SINV-1, SINV-2, and SINV-3 among larval and worker S. invicta ants. Virus was quantified by real-time PCR. Color key reflects the proportion of the total for each virus detected in each tissue. (ND = not detected). Tissue key is identical for all viruses, H: head; Th: thorax; C: crop; Mg: midgut; Hg: hindgut; PS: poison sac; Mt: Malpighian tubules; AbC: abdominal carcass, AC: alimentary canal; Car: carcass.

[83]. Thus, larvae not only appear to serve as reservoirs for SINV-1, but also conduits for SINV-1 colonial dissemination (Figure 5).

Evidence for the importance of the alimentary canal in the horizontal transmission of dicistroviruses is further illustrated by the presence of virus particles in the excreta of infected hosts. The excreta serves as an important source of viral inoculum for Plautia stali intestine virus (PSIV) [84], Black queen cell virus (BQCV), Acute bee paralysis virus (ABPV), [85] Kashmir bee virus (KBV) [86], HiPV [87], and $\operatorname{TrV}[80]$. The fecal-oral route of infection has even been shown to play a prominent role in the infection process of many of the Picornaviridae in mammals [88].

SINV-1 was detected in all developmental stages of $S$. invicta including eggs and queens indicating vertical transmission of the virus $[25,73,74]$. Larval and worker ants generally exhibited the highest viral loads reaching levels of $10^{8}$ to $10^{9}$ per individual [74]. The SINV-1 titer was generally similar between larvae and workers collected from the same colony. A positive relationship was observed between the SINV-1 titer in individual ants and intracolony SINV-1 prevalence; colonies with higher intracolony 


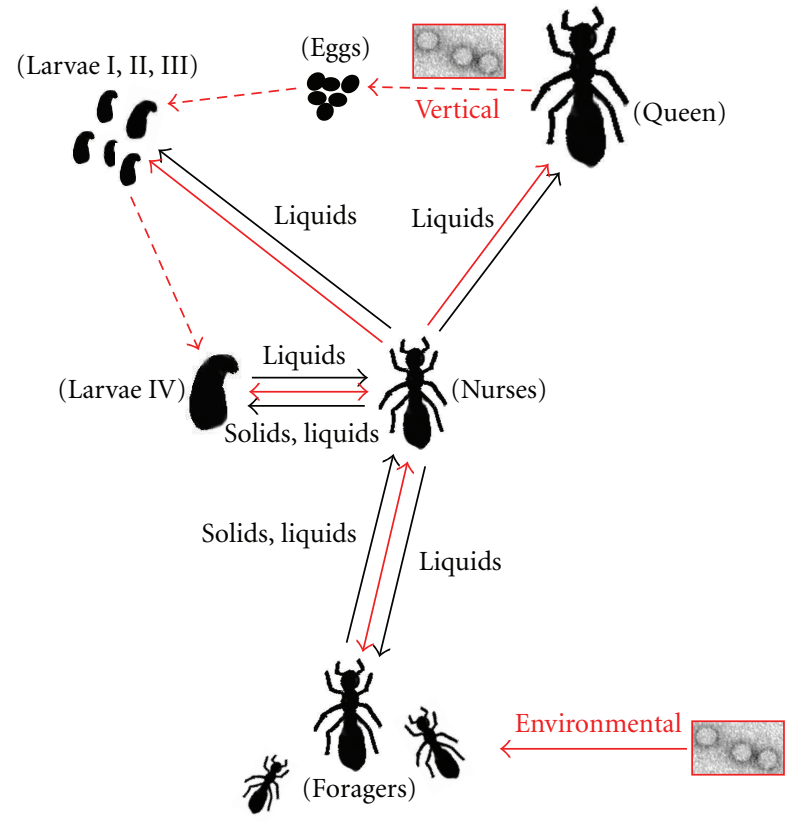

FIGURE 5: Routes proposed for SINV-1 (and possibly SINV-2 and SINV-3) colony acquisition and dissemination [81]. SINV-1 exhibits a tissue tropism toward the midgut, and large quantities of virus are detected in the midgut contents of adults and larvae of infected colonies. Thus, colony dissemination of SINV-1 appears to coincide with the food distribution route for the colony. Black arrows illustrate the flow of food throughout the colony and red arrows the corresponding movement of SINV-1. Two modes of virus acquisition are likely environmental (from outside sources entering the colony by way of foragers) and vertical (from infected queens). The vertical route of distribution is illustrated by broken red lines. The food flow diagram was adapted from Vinson and Sorensen [82].

SINV-1 prevalence exhibited higher SINV-1 titers among individuals [73].

3.4. Colony Effects. Initially, SINV-1 was associated with larval mortality in laboratory S. invicta colonies but no observable symptoms were detected among field populations [25]. A number of factors, including undetected pathogens and the inability to produce pure SINV-1 have limited the ability to directly infect colonies with SINV-1 and measure the impact of the infection on individual ants and colonies. SINV-1 appears to conform to the paradigm of many arthropodinfecting positive, single-stranded RNA viruses. Specifically, the virus persists as a chronic, asymptomatic infection that does not cause any overt signs or symptoms. However, under certain circumstances (e.g., environmental stress) the virus replicates rapidly causing overt symptoms and even death [89-91].

A recent series of experiments examined the ability of SINV-1-infected and -uninfected S. invicta ants and colonies to compete with native ant species Pheidole fervens and Monomorium chinense [92]. SINV-1-infected S. invicta were more quickly eliminated by $M$. chinense than healthy $S$. invicta. Direct confrontation tests confirmed these results;
M. chinense killed significantly more $S$. invicta minors from SINV-1-infected colonies compared with healthy colonies. Against $P$. fervens, SINV-1-infected $S$. invicta required significantly more time to eliminate competing $P$. fervens colonies compared with healthy $S$. invicta. The study revealed that SINV-1 infection weakened the competitive ability of $S$. invicta and made them more susceptible to elimination by some species of sympatric ants, like M. chinense.

\section{Solenopsis invicta Virus 2}

SINV-2 is the second virus discovered that infects the red imported fire ant, S. invicta [26]. This virus possesses a genome structure that is unique and differs considerably from currently described positive, single-stranded RNA viruses. As with SINV-1, the SINV-2 genome was constructed by compiling sequences from successive $5^{\prime}$ and $3^{\prime}$ RACE reactions using an expressed sequence tag (Genbank accession EH413675) as the initial anchor template (Figure 2). The genome (Genbank accession EF428566) was monopartite, 11,303 nucleotides in length, polyadenylated at the $3^{\prime}$ end, $\mathrm{A} / \mathrm{U}$ rich $(27.9 \% \mathrm{~A}, 28.9 \% \mathrm{U}, 20.1 \% \mathrm{C}, 23.1 \% \mathrm{G})$, and encoded 4 major ORFs (comprised of $\geq 100$ codons) in the sense orientation (Figure 2). Untranslated regions were present on the $5^{\prime}$ (nts 1-301) and $3^{\prime}$ ends (nts 1091711303 ) of the genome. Intergenic regions were also indicated between ORFs 1 and 2 (nts 1079-1828), and ORFs 3 and 4 (nts 3793-4454). ORFs 2 and 3 overlap a stop and start codon, respectively, and are not, therefore, interrupted by an intergenic region. ORF 3 was in the first reading frame, ORFs 1 and 2 were in the second reading frame, and ORF 4 was in the third reading frame. ORFs 1 through 4 encoded predicted proteins of 29,$413 ; 31,160 ; 43,224 ; 246,845 \mathrm{Da}$, respectively. Blastp analysis [34] of SINV-2 ORF 4 identified regions with significant identity to RdRp, helicase, and protease conserved domains from positive, single-stranded RNA viruses [35] (Figure 2). Blastp analysis of ORFs 1, 2, and 3 yielded poor identity (expectation scores greater than 1) to corresponding capsid proteins from positive, single-stranded RNA viruses.

The monopartite, multiple ORF-encoding genome structure of SINV-2 is unique. Regions of the polyprotein encoded by SINV-2 ORF 4 exhibited identity with RdRp and helicase domains characteristic of positive, single-stranded RNA viruses. However, only a partial domain for a protease was recognized near the amino end of the ORF 4 polyprotein (amino acid residues 330 to 410). A similarly unique genome structure was reported for the Nora virus, an unclassified virus that persistently infects Drosophila melanogaster [93]. The Nora virus genome is also monopartite and encodes 4 major ORFs. In addition to genome structural similarities, Nora virus and SINV-2 contained truncated protease domains [93]. Amino acids thought to form the catalytic triad of the protease $(\mathrm{H}, \mathrm{E}, \mathrm{C})$ and the consensus $\mathrm{GxCG}$ sequence motif were absent in all ORFs of SINV-2 [94, 95]. Additional differences between Nora virus and SINV2 included positional relationships of the nonstructural proteins and relative ORF positions. 
S. invicta colonies infected with SINV-2 did not exhibit any discernable symptoms in the field or consistently when reared in the laboratory. Occasionally, infected laboratory colonies exhibited brood die-off. Whether SINV-2 was responsible for this pathology was undetermined. The negative strand of the SINV-2 genome was detected in larvae and adults of $S$. invicta indicating that the virus was replicating [96].

SINV-2 host specificity evaluations have not been conducted. All developmental stages of S. invicta have been shown to be infected with SINV-2, including the queen and eggs suggesting vertical transmission of the virus [97]. Larvae and workers generally exhibited the highest viral load. Horizontal transmission of SINV-2 to uninfected S. invicta colonies was accomplished by feeding a homogenate of SINV2 -infected ants [97]. Tissue specificity of SINV-2 closely reflected that of SINV-1. The midgut of workers and alimentary canal of larvae possessed the highest quantities of SINV-2 (Figure 4).

\section{Solenopsis invicta Virus 3}

SINV-3 is the most recent virus to be discovered from S. invicta using the metagenomics approach $[24,33]$ and it also possesses features consistent with placement within the order Picornavirales [35]. As with SINV-1 and -2, the genome of SINV-3 was constructed by compiling sequences from successive $5^{\prime}$ and $3^{\prime}$ RACE reactions using an EST sequence (Genbank accession EH413252) as anchor template. SINV3 possesses a genome that is 10,386 nucleotides in length, excluding the poly(A) tail present on the $3^{\prime}$ end (Genbank accession FJ528584). Also consistent with SINV-1 and -2, the SINV-3 genome was A/U rich (70.9\% A/U; 29.1\% G/C). It encodes 2 large ORFs in the sense orientation with a UTR at each end and between the two ORFs (Figure 2). The 5' proximal ORF (ORF 1) began at nucleotide position 92 and ended at a UGA stop codon at nucleotide 7,834 yielding a predicted polyprotein of $299,095 \mathrm{Da}$ (2,580 amino acids). The 3' proximal ORF (ORF 2), commenced at nucleotide position 8,308 , terminated at nucleotide position 10,263 and encoded a predicted protein of 73,186 Da (651 amino acids). No large ORFs were found in the inverse orientation. The $5^{\prime}, 3^{\prime}$, and intergenic UTRs were comprised of 91, 123, and 473 nucleotides, respectively. Blastp analysis [34] of the polyprotein encoded by ORF 1 identified conserved domains for RdRp, protease, and helicase (Figure 2). Blastp analysis of the ORF 2 polyprotein did not yield any sequences with significant identity.

For comparison, the genome of an Argentinean isolate of SINV-3 (SINV-3 $3^{\mathrm{ArgSF}}$ ) obtained from the Santa Fe region of Argentina was sequenced in entirety [98]. Argentina is thought to be the region from which the USA S. invicta population originated [99]. Excluding the poly(A) tail, the genome length of SINV-3 ${ }^{\operatorname{ArgSF}}$ (Genbank accession GU 017972) was identical to the North American isolate (referred to as SINV-3). The SINV-3 ${ }^{\mathrm{ArgSF}}$ genome possessed 3 major ORFs in the sense orientation; SINV-3 possessed only two ORFs [24]. Both isolates exhibited identical start and stop codon positions for ORFs 1 and 2. Blastp analysis of the translated ORF 1 of SINV-3 ${ }^{\mathrm{ArgSF}}$ recognized conserved domains for helicase, protease, and RdRp, and their corresponding positions were identical to those reported for SINV-3. ORF 3, unique to the SINV-3 ${ }^{\mathrm{ArgSF}}$ genome (Figure 2), was located at nucleotide positions 8,351 through 8,827 and overlapped ORF 2. ORF 3 yielded a predicted protein sequence comprised of 158 amino acids with a molecular mass of $18.8 \mathrm{kDa}$. Blastp analysis of the translated amino acid sequence of ORF 3 revealed no significant similarity in the Genbank database.

The two SINV-3 isolates exhibited 96.2\% nucleotide sequence identity across the entire genome [98]. The 5', 3' and intergenic UTRs of the genomes exhibited 100, 99.2, and 92.6\% identities, respectively. The amino acid sequences of ORFs 1 and 2 exhibited 99.0 and 96.6\% identities, respectively, indicating that the nucleotide differences between isolates were largely synonymous. Indeed, the proportion of amino acid residues that were similar in ORFs 1 and 2 were even higher $(99.6 \%$ and $98.2 \%$, resp.).

Tracking changes in pathogen genomes (including viruses) can be a useful and indirect method of providing information about their hosts $[59,100]$ and have been employed to construct demographic histories of host populations [101]. Unlike SINV-1 [59], comparison of the genome sequences of SINV-3 isolates indicated that no significant directional selection has occurred despite separation of the host populations geographically (Argentina/United States) and temporally (approximately 70 years). Thus, SINV-3 may have been a relatively recent introduction into the North American S. invicta population. SINV-1, -2, and -3 may aid a number of phylogenetic-based studies and reveal information about movement and establishment of the S. invicta host population.

SINV-3 infects all developmental stages of S. invicta, including the queen and eggs suggesting that vertical transmission occurs. Unlike SINV-1 and SINV-2, SINV-3 exhibits a broad tissue tropism. SINV-3 was detected in all tissues of S. invicta queens, workers and larvae examined (Figure 4). Thus, the SINV-3 infection appears to be systemic. This systemic characteristic appears to coincide with the association between SINV-3 infection and significant mortality among S. invicta laboratory colonies [24]. Signs of infection included large midden piles of ants, brood mortality, and colony collapse. Dead, dried brood found on the midden piles exhibit a crystallized appearance. Some workers may remain alive for considerable periods after the initial die-off, and occasionally, if the queen survived, colonies will rebound exhibiting normal brood production.

Although SINV-1, SINV-2, and SINV-3 are all positive, single-strand RNA viruses infecting $S$. invicta, they exhibit differences in their genome organizations; SINV-1 and SINV3 encode 2 ORFs, while SINV-2 encodes 4 ORFs. However, the most important difference between SINV-1, SINV-2, and SINV-3 is pathogenicity. SINV-1 and -2 appear to cause chronic, asymptomatic infections that may result in mortality under certain stressful conditions, as reported in honeybees [90]. Although SINV-1 and SINV-2 were regularly transmitted to healthy colonies of S. invicta ants by feeding, 


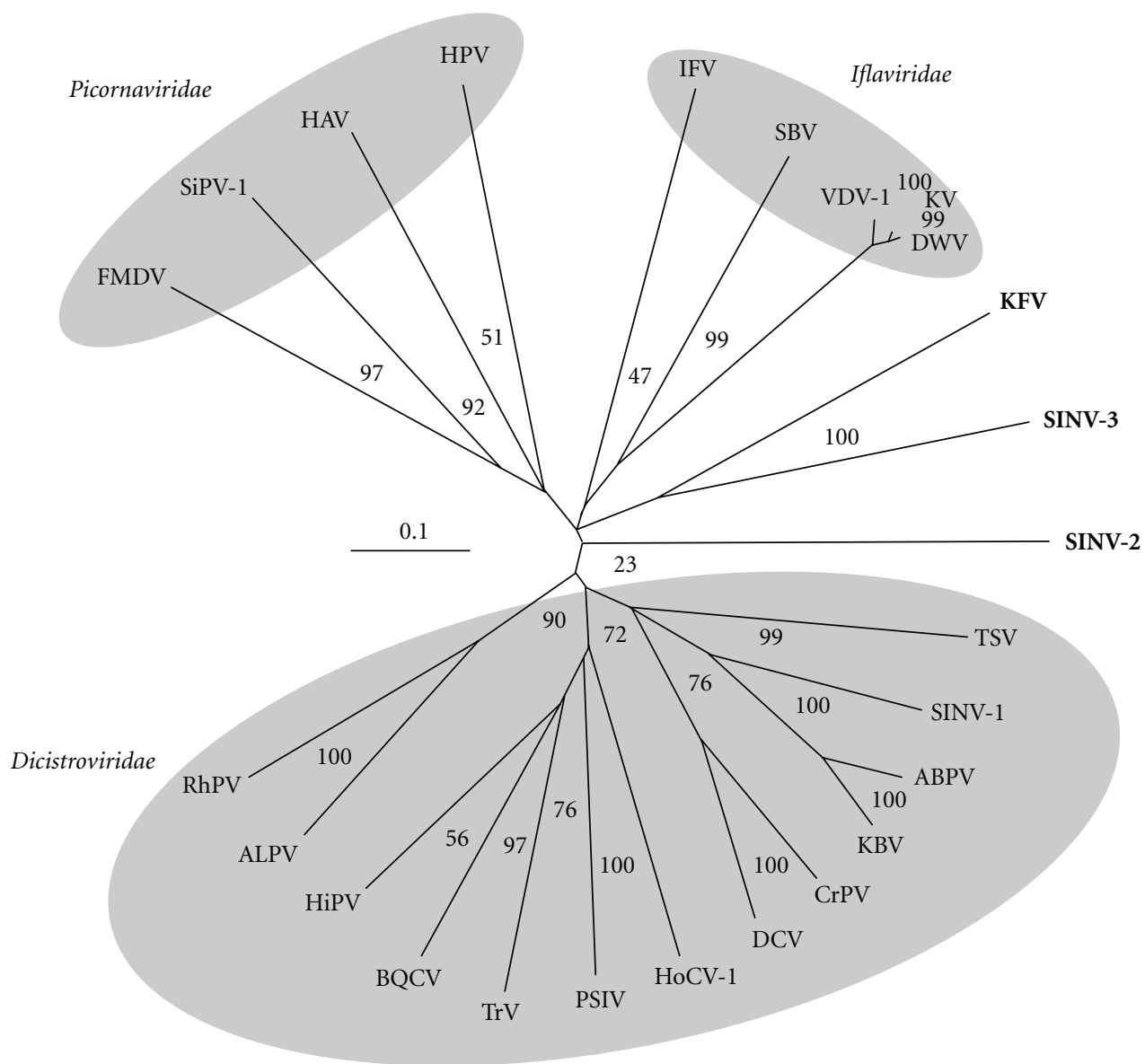

FIGURE 6: Phylogenetic analysis of the conserved amino acid sequences containing domains I to VIII of the putative RdRp from 13 dicistroviruses, 5 iflaviruses, 4 picornaviruses, and 3 unassigned viruses (bold). Virus abbreviation, Genbank accession number of the virus sequence, and amino acid residues of aligned sequences in a specific ORF ( $5^{\prime}$ proximal ORF of dicistroviruses, otherwise an ORF number is specified) include the following. Aphid lethal paralysis virus (ALPV) [AF536531], 1661-1955; Black queen cell virus (BQCV) [NP620564], 1317-1585; Cricket paralysis virus (CrPV) [NP647481], 1423-1697; Drosophila C virus (DCV) [AF014388], 1415-1693; Himetobi P virus (HiPV) [AB017037], 1441-1710; Plautia stali intestine virus (PSIV) [NP620555], 1465-1739; Rhopalosiphum padi virus (RhPV) [AF022937], 1625-1916; Triatoma virus (TrV) [AF178440], 1446-1716; Acute bee paralysis virus (ABPV) [AAG13118], 15661837; Homalodisca coagulata virus-1 (HoCV-1) [DQ288865], 1446-1716; Kashmir bee virus (KBV) [AY275710], 1594-1864; Solenopsis invicta virus-1 (SINV-1) [AY634314], 1052-1327; Taura syndrome virus (TSV) [AF277675], 1770-2036; Infectious flacherie virus (IFV) [AB000906], 2618-2888; Sacbrood virus (SBV) [NC002066], 2522-2790; Deformed wing virus (DWV) [AJ489744], 2556-2826; Kakugo virus (KV) [AB070959], 2556-2826; Varroa destructor virus 1 (VDV-1) [AY251269], 2556-2826; Foot-and-mouth disease virus (FMDV) [AF308157], 2011-2264; Hepatitis A virus (HAV) [NC001489], 1904-2161; Human parechovirus (HPV) [AJ005695], 1871-2117; Simian picornavirus 1 (SiPV-1) [AY064708], 2119-2368; Solenopsis invicta virus 2 (SINV-2) ORF 4 [ABQ01575], 1814-2081; Kelp fly virus (KFV) [YP415507], 3015-3272; Solenopsis invicta virus 3 (SINV-3) ORF 1, 1848-2107.

mortality among recipient colonies was an occasional event [25]. On the other hand, SINV-3 was associated consistently with ant mortality and a correspondingly high SINV-3 titer ( $>10^{9}$ viral particles in a single dead ant carcass). Furthermore, SINV-3 was detected systemically-unlike SINV-1 and SINV-2 which were largely limited to the gut $[73,74,97]$.

SINV-3 is readily transmitted to healthy colonies in the laboratory by exposure to homogenates of SINV-3-infected ants and by simply being confined in areas containing SINV3-infected colonies (SMV unpublished). SINV-3-containing fire ant body parts become friable and airborne, contaminating surrounding areas. Disinfection of contaminated areas is extremely difficult. However, hypochlorite solution is an effective means of disinfection.

\section{S. invicta Virus Phylogenetic Analysis}

Phylogenetic analysis of the conserved amino acid sequences containing domains I to VIII of the RdRp from representative dicistroviruses, iflaviruses, picornaviruses, and unassigned positive, single-stranded RNA viruses revealed a phenogram with SINV-1 clearly part of the Dicistroviridae, SINV-2 forming its own unique clade, and SINV-3 and Kelp fly virus (KFV) comprising a unique group (Figure 6). SINV-1 has 
been placed formally into the Dicistroviridae family [102] and the recently proposed Aparavirus genus (pending approval from the International Committee for the Taxonomy of Viruses). Bootstrap values between the major clusters and SINV-2 were relatively low indicating an uncertain common ancestor for this virus. This independent placement of SINV2 is further supported by phylogenetic results for the helicase region of ORF 1 [26]. SINV-3 is also unique, but exhibits a relationship with KFV. Both of these viruses exhibited a small virion size $(27.3 \pm 1.3 \mathrm{~nm}$ diameter $)$ with apparent surface projections [103] and a high buoyant density (1.39 \pm $0.02 \mathrm{~g} / \mathrm{mL}$ ). They also appear to possess only 2 major capsid proteins (VP1 and VP2) as opposed to 3 or 4 which is typical of the Iflaviridae and Dicistroviridae. The capsid proteins of KFV and SINV-3 exhibited poor comparative sequence identity $(<10 \%)$.

\section{Potential as Control Agents}

SINV-1, -2 , and -3 represent the only known viruses infecting any ant (Hymenoptera: Formicidae) species. As stated, the intention of virus discovery in S. invicta was to utilize viruses as novel control agents against this ant pest. Development and use of positive, single-stranded RNA viruses as insect control agents has been proposed $[104,105]$ and successfully demonstrated for a number of insect pests. CrPV was evaluated against the olive fruit fly, Dacus oleae, and shown to cause up to $80 \%$ mortality [106]. CrPV was also reported to be an effective control agent for adult Mediterranean fruit flies, Ceratitis capitata [107]. High rates of mortality were observed in laboratory and field tests of RNA viruses against Epicerura pergrisea and Latoia viridissima in Côte d'Ivoire $[108,109]$. Unfortunately, a major limitation of the use of RNA viruses in insect control is large-scale production. This problem can be ameliorated when virus growth is supported by a cell line. However, insect host cell lines supporting viral production are available for only a handful of viruses. Indeed, the absence of a fire ant cell line has hampered investigation and development of the Solenopsis invicta viruses as microbial control agents. However, alternative methods of virus production have been demonstrated.

Production of infectious RNA transcripts [110-112] and in vitro baculovirus-driven expression of insect-infecting positive, single-stranded RNA viruses have been reported [113]. These methods facilitate study of virus biology and provide a means for their large-scale production. Development of a SINV-3 construct and subsequent in vitro expression of SINV-3 has been underway in our laboratory for the last year. Successful transcription of the SINV-3 genome has been accomplished, but production of encapsidated SINV-3 genome has not been observed (SMV unpublished). Indeed, transcript production and translation have proven extremely limited in this system. Because SINV-3 is associated with significant mortality among $S$. invicta colonies (reminiscent of colony collapse disorder of honeybees), our research is focused on studying this virus, including production, host specificity, efficacy, dose responses, mechanisms of action, and development as a biopesticide. Although SINV-1 and
SINV-2 appear to cause chronic, asymptomatic infections, they might find utility as control agents once their biology is more fully understood. Sodium alginate microencapsulated formulations of SINV-1 have been demonstrated to successfully transmit virus to uninfected colonies [114]. SINV-1 and -2 may also be exploited in unique ways, for example, as delivery vehicles for toxins or RNA interfering molecules after modification. Only through additional research to characterize the biology of these viruses will their full potential as control agents be realized.

\section{Acknowledgments}

The author thanks Dr. Anne-Marie Callcott for providing the historical quarantine data for Solenopsis invicta and Solenopsis richteri. He also thanks Drs. D. H. Oi, M. Y. Choi and J. J. Becnel for reviews of an earlier manuscript and S.D. Porter for helpful discussions on the historical perspectives of fire ant range expansion. The use of trade, firm, or corporation names in this publication are for the information and convenience of the reader. Such use does not constitute an official endorsement or approval by the United States Department of Agriculture or Agricultural Research Service of any product or service to the exclusion of others that may be suitable.

\section{References}

[1] W. S. Creighton, "The new world species of the genus Solenopsis (Hymenoptera: Formicidae)," Proceedings of the American Academy of Arts of Sciences, vol. 66, no. 1, pp. 39151, 1930.

[2] W. R. Tschinkel, The Fire Ants, The Belknap Press of Harvard University Press, Cambridge, Mass, USA, 2006.

[3] A. M. Callcott and H. L. Collins, "Invasion and range expansion of imported fire ants (Hymenoptera: Formicidae) in North America from 1918-1995," The Florida Entomologist, vol. 79, no. 2, pp. 240-248, 1996.

[4] D. F. Williams, H. L. Collins, and D. H. Oi, “The red imported fire ant (Hymenoptera: Formicidae): an historical perspective of treatment programs and the development of chemical baits for control," The American Entomologist, vol. 47, no. 3, pp. 146-159, 2001.

[5] R. M. Pereira, "Areawide suppression of fire ant populations in pastures: project update," Journal of Agricultural and Urban Entomology, vol. 20, no. 3, pp. 123-130, 2003.

[6] S. D. Porter, H. G. Fowler, and W. P. Mackay, "Fire ant mound densities in the United States and Brazil (Hymenoptera: Formicidae)," Journal of Economic Entomology, vol. 85, no. 4, pp. 1154-1161, 1992.

[7] S. D. Porter, D. F. Williams, R. S. Patterson, and H. G. Fowler, "Intercontinental differences in the abundance of Solenopsis fire ants (Hymenoptera: Formicidae): escape from natural enemies?" Environmental Entomology, vol. 26, no. 2, pp. 373384, 1997.

[8] M. E. Torchin, K. D. Lafferty, A. P. Dobson, V. J. McKenzie, and A. M. Kuris, "Introduced species and their missing parasites," Nature, vol. 421, no. 6923, pp. 628-630, 2003.

[9] J. Prenter, C. MacNeil, J. T. A. Dick, and A. M. Dunn, "Roles of parasites in animal invasions," Trends in Ecology and Evolution, vol. 19, no. 7, pp. 385-390, 2004. 
[10] D. F. Williams, D. H. Oi, S. D. Porter, R. M. Pereira, and J. A. Briano, "Biological control of imported fire ants (Hymenoptera: Formicidae)," The American Entomologist, vol. 49, no. 3, pp. 150-163, 2003.

[11] D. P. Jouvenaz, "Natural enemies of fire ants," The Florida Entomologist, vol. 66, no. 1, pp. 111-121, 1983.

[12] D. P. Jouvenaz, G. E. Allen, W. A. Banks, and D. P. Wojcik, "A survey for pathogens of fire ants, Solenopsis spp. in the southeastern United States," The Florida Entomologist, vol. 60, pp. 275-279, 1977.

[13] D. P. Jouvenaz, C. S. Lofgren, and W. A. Banks, "Biological control of imported fire ants; a review of current knowledge," Bulletin of the Entomological Society of America, vol. 27, no. 2, pp. 203-208, 1981.

[14] D. P. Wojcik, D. P. Jouvenaz, and W. A. Banks, "Biological control agents of fire ants in Brazil," in Chemistry and Biology of Social Insects, J. Eder and H. Rembold, Eds., pp. 627-628, Peperny, Munich, Germany, 1987.

[15] D. P. Jouvenaz and J. W. Kimbrough, "Myrmecomyces annellisae gen. nov., sp. nov. (Deuteromycotina: Hypomycetes), an endoparasitic fungus of fire ants, Solenopsis spp. (Hymenoptera: Formicidae)," Mycological Research, vol. 95, no. 12, pp. 1395-1401, 1991.

[16] R. M. Pereira, "Occurrence of Myrmicinosporidium durum in red imported fire ant, Solenopsis invicta, and other new host ants in eastern United States," Journal of Invertebrate Pathology, vol. 86, no. 1-2, pp. 38-44, 2004.

[17] J. D. Knell and G. E. Allen, "Light and electron microscope study of Thelohania solenopsae n. sp. (Microsporida: Protozoa) in the red imported fire ant, Solenopsis invicta," Journal of Invertebrate Pathology, vol. 29, no. 2, pp. 192-200, 1977.

[18] D. F. Williams, G. J. Knue, and J. J. Becnel, "Discovery of Thelohania solenopsae from the red imported fire ant, Solenopsis invicta, in the United States," Journal of Invertebrate Pathology, vol. 71, no. 2, pp. 175-176, 1998.

[19] R. M. Pereira, D. F. Williams, J. J. Becnel, and D. H. Oi, "Yellow-head disease caused by a newly discovered Mattesia sp. in populations of the red imported fire ant, Solenopsis invicta," Journal of Invertebrate Pathology, vol. 81, no. 1, pp. 45-48, 2002.

[20] S. M. Valles and R. M. Pereira, "Use of ribosomal DNA sequence data to characterize and detect a neogregarine pathogen of Solenopsis invicta (Hymenoptera: Formicidae)," Journal of Invertebrate Pathology, vol. 84, no. 2, pp. 114-118, 2003.

[21] J. Kathirithamby and J. S. Johnston, "Stylopization of Solenopsis invicta (Hymenoptera: Formicidae) by Caenocholax fenyesi (Strepsiptera: Myrmecolacidae) in Texas," Annals of the Entomological Society of America, vol. 85, no. 2, pp. 293297, 2001.

[22] A. M. Callcott, S. D. Porter, R. D. Weeks Jr., L. C. Graham, S. J. Johnson, and L. E. Gilbert, "Fire ant decapitating fly cooperative release programs (1994-2008): two Pseudacteon species (P. tricuspis, P. curvatus) rapidly expand across imported fire ant populations in the southeastern United States," Journal of Insect Science, vol. 11, no. 19, pp. 1-25, 2010.

[23] S. D. Porter, "Biology and behavior of Pseudacteon decapitating flies (Diptera: Phoridae) that parasitize Solenopsis fire ants (Hymenoptera: Formicidae)," The Florida Entomologist, vol. 81, no. 3, pp. 292-309, 1998.

[24] S. M. Valles and Y. Hashimoto, "Isolation and characterization of Solenopsis invicta virus 3, a new postive-strand RNA virus infecting the red imported fire ant, Solenopsis invicta," Virology, vol. 388, no. 2, pp. 354-361, 2009.
[25] S. M. Valles, C. A. Strong, P. M. Dang et al., "A picorna-like virus from the red imported fire ant, Solenopsis invicta: initial discovery, genome sequence, and characterization," Virology, vol. 328, no. 1, pp. 151-157, 2004.

[26] S. M. Valles, C. A. Strong, and Y. Hashimoto, "A new positivestrand RNA virus with unique genome characteristics from the red imported fire ant, Solenopsis invicta," Virology, vol. 365, no. 2, pp. 457-463, 2007.

[27] C. C. Yang, Y. C. Yu, S. M. Valles et al., "Loss of microbial (pathogen) infections associated with recent invasions of the red imported fire ant Solenopsis invicta," Biological Invasions, vol. 12, no. 9, pp. 3307-3318, 2010.

[28] S. D. Porter, L. A. Nogueira de Sa, and L. W. Morrison, "Establishment and dispersal of the fire ant decapitating fly Pseudacteon tricuspis in North Florida," Biological Control, vol. 29, no. 2, pp. 179-188, 2004.

[29] C. S. Lofgren, "History of imported fire ants in the United States," in Fire Ants and Leaf-Cutting Ants Biology and Management, C. S. Lofgren and R. K. Vander Meer, Eds., pp. 3647, Westview Press, Boulder, Colo, USA, 1986.

[30] L. A. Lacey, R. Frutos, H. K. Kaya, and P. Vail, "Insect pathogens as biological control agents: do they have a future?" Biological Control, vol. 21, no. 3, pp. 230-248, 2001.

[31] S. W. Avery, D. P. Jouvenaz, W. A. Banks, and D. W. Anthony, "Virus-like particles in a fire ant, Solenopsis sp., (Hymenoptera: Formicidae) from Brazil," The Florida Entomologist, vol. 60, no. 1, pp. 17-20, 1977.

[32] S. B. Vinson and L. Greenberg, "The biology, physiology, and ecology of imported fire ants," in Economic Impact and Control of Social Insects, S. B. Vinson, Ed., pp. 193-226, Praeger Scientific, New York, NY, USA, 1986.

[33] S. M. Valles, C. A. Strong, W. B. Hunter et al., "Expressed sequence tags from the red imported fire ant, Solenopsis invicta: annotation and utilization for discovery of viruses," Journal of Invertebrate Pathology, vol. 99, no. 1, pp. 74-81, 2008.

[34] S. F. Altschul, T. L. Madden, A. A. Schäffer et al., "Gapped BLAST and PSI-BLAST: a new generation of protein database search programs," Nucleic Acids Research, vol. 25, no. 17, pp. 3389-3402, 1997.

[35] O. Le Gall, P. Christian, C. M. Fauquet et al., "Picornavirales, a proposed order of positive-sense single-stranded RNA viruses with a pseudo-T $=3$ virion architecture," Archives of Virology, vol. 153, no. 4, pp. 715-727, 2008.

[36] S. Cherry and N. Silverman, "Host-pathogen interactions in drosophila: new tricks from an old friend," Nature Immunology, vol. 7, no. 9, pp. 911-917, 2006.

[37] X. H. Wang, R. Aliyari, W. X. Li et al., "RNA interference directs innate immunity against viruses in adult Drosophila," Science, vol. 312, no. 5772, pp. 452-454, 2006.

[38] J. Mari, B. T. Poulos, D. V. Lightner, and J. R. Bonami, "Shrimp Taura syndrome virus: genomic characterization and similarity with members of the genus Cricket paralysislike viruses," Journal of General Virology, vol. 83, part 4, pp. 915-926, 2002.

[39] N. Nakashima and N. Shibuya, "Multiple coding sequences for the genome-linked virus protein ( $\mathrm{VPg}$ ) in dicistroviruses," Journal of Invertebrate Pathology, vol. 92, no. 2, pp. 100104, 2006.

[40] A. V. Paul, "Possible unifying mechanism of pircornavirus genome replication," in Molecular Biology of Picornaviruses, B. L. Semler and E. Wimmer, Eds., pp. 227-246, American Society for Microbiology, Washington, DC, USA, 2003.

[41] N. Nakashima and Y. Nakamura, "Cleavage sites of the "P3 region" in the nonstructural polyprotein precursor of a 
dicistrovirus," Archives of Virology, vol. 153, no. 10, pp. 19551960, 2008.

[42] S. M. Valles and Y. Hashimoto, "Characterization of structural proteins of Solenopsis invicta virus 1," Virus Research, vol. 136, no. 1-2, pp. 189-191, 2008.

[43] A. V. Pisarev, N. E. Shirokikh, and C. U. T. Hellen, "Translation initiation by factor-independent binding of eukaryotic ribosomes to internal ribosomal entry sites," Critical Reviews in Biology, vol. 328, no. 7, pp. 589-605, 2005.

[44] E. Jan, "Divergent IRES elements in invertebrates," Virus Research, vol. 119, no. 1, pp. 16-28, 2006.

[45] G. Lanzi, J. R. de Miranda, M. B. Boniotti et al., "Molecular and biological characterization of deformed wing virus of honeybees (Apis mellifera L.)," Journal of Virology, vol. 80, no. 10, pp. 4998-5009, 2006.

[46] L. Liljas, J. Tate, T. Lin, P. Christian, and J. E. Johnson, "Evolutionary and taxonomic implications of conserved structural motifs between picornaviruses and insect picorna-like viruses," Archives of Virology, vol. 147, no. 1, pp. 59-84, 2002.

[47] J. R. de Miranda, M. Drebot, S. Tyler et al., "Complete nucleotide sequence of Kashmir bee virus and comparison with acute bee paralysis virus," Journal of General Virology, vol. 85, part 8, pp. 2263-2270, 2004.

[48] E. Maori, S. Lavi, R. Mozes-Koch et al., "Isolation and characterization of Israeli acute paralysis virus, a dicistrovirus affecting honeybees in Israel: evidence for diversity due to intra- and inter-species recombination," Journal of General Virology, vol. 88, part 12, pp. 3428-3438, 2007.

[49] N. Sabath, N. Price, and D. Graur, "A potentially novel overlapping gene in the genomes of Israeli acute paralysis virus and its relatives," Virology Journal, vol. 6, no. 6, article 144, 2009.

[50] B. C. Bonning, "The dicistroviridae: an emerging family of invertebrate viruses," Virologica Sinica, vol. 24, no. 5, pp. 415427, 2009.

[51] B. C. Bonning and W. A. Miller, "Dicistroviruses," Annual Review of Entomology, vol. 55, pp. 129-150, 2010.

[52] N. Nakashima and T. Uchiumi, "Functional analysis of structural motifs in dicistroviruses," Virus Research, vol. 139, no. 2, pp. 137-147, 2008.

[53] M. I. Hertz and S. R. Thompson, "In vivo functional analysis of the Dicistroviridae intergenic region internal ribosome entry sites," Nucleic Acids Research, vol. 39, no. 16, pp. 7276$7288,2011$.

[54] E. Maori, E. Tanne, and I. Sela, "Reciprocal sequence exchange between non-retro viruses and hosts leading to the appearance of new host phenotypes," Virology, vol. 362, no. 2, pp. 342-349, 2007.

[55] E. Tanne and I. Sela, "Occurrence of a DNA sequence of a non-retro RNA virus in a host plant genome and its expression: evidence for recombination between viral and host RNAs," Virology, vol. 332, no. 2, pp. 614-622, 2005.

[56] S. Crochu, S. Cook, H. Attoui et al., "Sequences of flavivirusrelated RNA viruses persist in DNA form integrated in the genome of Aedes spp. mosquitoes," Journal of General Virology, vol. 85, no. 7, pp. 1971-1980, 2004.

[57] S. M. Valles and B. Bextine, "Examination of host genome for the presence of integrated fragments of Solenopsis invicta virus 1," Journal of Invertebrate Pathology, vol. 107, no. 3, pp. 212-215, 2004.

[58] S. M. Valles, C. A. Strong, D. H. Oi et al., "Phenology, distribution, and host specificity of Solenopsis invicta virus1," Journal of Invertebrate Pathology, vol. 96, no. 1, pp. 18-27, 2007.
[59] C. Allen, J. A. Briano, L. Varone, D. H. Oi, and S. M. Valles, "Exploitation of a high genomic mutation rate in Solenopsis invicta virus 1 to infer demographic information about its host, Solenopsis invicta," Journal of Invertebrate Pathology, vol. 105, no. 1, pp. 105-111, 2010.

[60] S. M. Valles, L. Varone, L. Ramírez, and J. Briano, "Multiplex detection of Solenopsis invicta viruses -1, -2, and -3," Journal of Virological Methods, vol. 162, no. 1-2, pp. 276-279, 2009.

[61] H. R. Allen, S. M. Valles, and D. M. Miller, "Characterization of Solenopsis invicta (Hymenoptera: Formicidae) populations in Virginia: social form genotyping and pathogen/parasitoid detection," The Florida Entomologist, vol. 93, no. 1, pp. 80-88, 2010.

[62] S. M. Valles and S. D. Porter, "Identification of polygyne and monogyne fire ant colonies (Solenopsis invicta) by multiplex PCR of Gp-9 alleles," Insectes Sociaux, vol. 50, no. 2, pp. 199200, 2003.

[63] S. M. Valles, D. H. Oi, and S. D. Porter, "Seasonal variation and the co-occurrence of four pathogens and a group of parasites among monogyne and polygyne fire ant colonies," $B i$ ological Control, vol. 54, no. 3, pp. 342-348, 2010.

[64] C. Allen, S. M. Valles, and C. A. Strong, "Multiple virus infections occur in individual polygyne and monogyne Solenopsis invicta ants," Journal of Invertebrate Pathology, vol. 107, no. 2, pp. 107-111, 2011.

[65] Y. P. Chen, N. Nakashima, P. Christian, B. C. Bonning, S. M. Valles, and D. V. Lightner, "Dicistroviridae," in Virus Taxonomy, Ninth Report of the ICTV, A. M. King, Ed., Elsevier, London, UK, in press.

[66] C. J. Jang and J. Eric, "Modular domains of the Dicistroviridae intergenic internal ribosome entry site," RNA, vol. 16, no. 6, pp. 1182-1195, 2010.

[67] S. M. Valles and C. A. Strong, "Solenopsis invicta virus-1A (SINV-1A): distinct species or genotype of SINV-1?" Journal of Invertebrate Pathology, vol. 88, no. 3, pp. 232-237, 2005.

[68] D. M. Tufts, W. B. Hunter, and B. Bextine, "Discovery and effects of Texas Solenopsis invicta virus [SINV-1 (TX5)] on red imported fire ant populations," Journal of Invertebrate Pathology, vol. 104, no. 3, pp. 180-185, 2010.

[69] E. Domingo and J. J. Holland, "RNA virus mutations and fitness for survival," Annual Review of Microbiology, vol. 51, pp. 151-178, 1997.

[70] J. J. Holland, K. Spindler, F. Horodyski, E. Grabau, S. Nichol, and S. VandePol, "Rapid evolution of RNA genomes," Science, vol. 215, no. 4540, pp. 1577-1585, 1982.

[71] S. M. Valles, "Ethanol preservation of fire ants allows retrospective screening for solenopsis invicta virus-1," The Florida Entomologist, vol. 90, no. 3, pp. 577-578, 2007.

[72] S. M. Valles and S. D. Porter, "Pseudacteon decapitating flies: potential vectors of a fire ant virus?" The Florida Entomologist, vol. 90, no. 1, pp. 268-270, 2007.

[73] Y. Hashimoto and S. M. Valles, "Solenopsis invicta virus-1 tissue tropism and intra-colony infection rate in the red imported fire ant: a quantitative PCR-based study," Journal of Invertebrate Pathology, vol. 96, no. 2, pp. 156-161, 2007.

[74] Y. Hashimoto, S. M. Valles, and C. A. Strong, "Detection and quantitation of Solenopsis invicta virus in fire ants by realtime PCR," Journal of Virological Methods, vol. 140, no. 1-2, pp. 132-139, 2007.

[75] J. R. de Miranda, G. Cordoni, and G. Budge, "The Acute bee paralysis virus-Kashmir bee virus-Israeli acute paralysis virus complex," Journal of Invertebrate Pathology, vol. 103, no. 1, pp. S30-S47, 2010. 
[76] Y. Chen, J. J. Becnel, and S. M. Valles, "RNA viruses infecting pest insects," in Insect Pathology, F. Vega and H. K. Kaya, Eds., Academic Press, San Diego, Calif, USA, in press.

[77] Y. Suzuki, S. Toriyama, I. Matsuda, and M. Kojima, "Detection of a picorna-like virus, himetobi $\mathrm{P}$ virus, in organs and tissues of Laodelphax striatellus by immunogold labeling and enzyme-linked immunosorbent assay," Journal of Invertebrate Pathology, vol. 62, no. 1, pp. 99-104, 1993.

[78] N. Lautie-Harivel, "Drosophila C virus cycle during the development of two Drosophila melanogaster strains (Charolles and Champetieres) after larval contamination by food," Biology of the Cell, vol. 76, no. 2, pp. 151-157, 1992.

[79] O. A. Muscio, J. L. LaTorre, and E. A. Scodeller, "Small nonoccluded viruses from triatomine bug Triatoma infestans (hemiptera: Reduviidae)," Journal of Invertebrate Pathology, vol. 49, no. 2, pp. 218-220, 1987.

[80] O. Muscio, M. A. Bonder, J. L. La Torre, and E. A. Scodeller, "Horizontal transmission of Triatoma virus through the fecal-oral route in Triatoma infestans (Hemiptera: Triatomidae)," Journal of Medical Entomology, vol. 37, no. 2, pp. 271$275,2000$.

[81] D. H. Oi and S. M. Valles, "Fire ant control with entomopathogens in the USA," in Use of Microbes for Control and Eradication of Invasive Arthropods, A. E. Hajek, T. R. Glare, and M. O'Callaghan, Eds., pp. 237-258, Springer Science, New York, NY, USA, 2009.

[82] S. B. Vinson and A. A. Sorensen, Imported Fire Ants: Life History and Impact, Texas A\&M University, College Station, 1986.

[83] B. Holldobler and E. O. Wilson, The Ants, Harvard University Press, Cambridge, Mass, USA, 1990.

[84] N. Nakashima, J. Sasaki, K. Tsuda, C. Yasunaga, and H. Noda, "Properties of a new picorna-like virus of the brown-winged green bug, Plautia stali," Journal of Invertebrate Pathology, vol. 71, no. 2, pp. 151-158, 1998.

[85] L. Bailey, B. V. Ball, and J. N. Perry, "The prevalence of viruses of honey bees in Britain," Annals of Applied Biology, vol. 103, no. 1, pp. 13-20, 1981.

[86] A. C. F. Hung, "PCR detection of Kashmir bee virus in honey bee excreta," Journal of Apicultural Research, vol. 39, no. 1-2, pp. 103-106, 2000.

[87] P. L. Guy, S. Toriyama, and S. Fuji, "Occurrence of a picornalike virus in planthopper species and its transmission in Laodelphax striatellus," Journal of Invertebrate Pathology, vol. 59, no. 2, pp. 161-164, 1992.

[88] V. R. Racaniello, "One hundred years of poliovirus pathogenesis," Virology, vol. 344, no. 1, pp. 9-16, 2006.

[89] L. Bailey, "The incidence of virus diseases in the honey bee," Annals of Applied Biology, vol. 60, no. 1, pp. 43-48, 1967.

[90] Y. P. Chen and R. Siede, "Honey bee viruses," Advances in Virus Research, vol. 70, no. 1, pp. 33-80, 2007.

[91] J. R. de Miranda and E. Genersch, "Deformed wing virus," Journal of Invertebrate Pathology, vol. 103, supplement 1, pp. S48-S61, 2010.

[92] Y.-C. Chen, L. Kafle, and C.-J. Shih, "Interspecific competition between Solenopsis invicta and two native ant species, Pheidole fervens and Monomorium chinense," Journal of Economic Entomology, vol. 104, no. 2, pp. 614-621, 2011.

[93] M. S. Habayeb, S. K. Ekengren, and D. Hultmark, "Nora virus, a persistent vitus in Drosophila, defines a new picornalike virus family," Journal of General Virology, vol. 87, no. 10, pp. 3045-3051, 2006.

[94] E. V. Koonin and V. V. Dolja, "Evolution and taxonomy of positive-strand RNA viruses: implications of comparative analysis of amino acid sequences," Critical Reviews in Biochemistry and Molecular Biology, vol. 28, no. 5, pp. 375-430, 1993.

[95] M. D. Ryan and M. Flint, "Virus-encoded proteinases of the picornavirus super-group," Journal of General Virology, vol. 78, no. 4, pp. 699-723, 1997.

[96] Y. Hashimoto and S. M. Valles, "Detection and quantitation of Solenopsis invicta virus-2 genomic and intermediary replicating viral RNA in fire ant workers and larvae," Journal of Invertebrate Pathology, vol. 98, no. 2, pp. 243-245, 2008.

[97] Y. Hashimoto and S. M. Valles, "Infection characteristics of Solenopsis invicta virus 2 in the red imported fire ant, Solenopsis invicta," Journal of Invertebrate Pathology, vol. 99, no. 2, pp. 136-140, 2008.

[98] S. M. Valles, C. Allen, L. Varone, and J. Briano, "Complete genome sequence of an Argentinean isolate of Solenopsis invicta virus 3," Virus Genes, vol. 40, no. 2, pp. 293-297, 2010.

[99] E. J. Caldera, K. G. Ross, C. J. DeHeer, and D. D. Shoemaker, "Putative native source of the invasive fire ant Solenopsis invicta in the USA," Biological Invasions, vol. 10, no. 8, pp. 1457-1479, 2008.

[100] T. Wirth, A. Meyer, and M. Achtman, "Deciphering host migrations and origins by means of their microbes," Molecular Ecology, vol. 14, no. 11, pp. 3289-3306, 2005.

[101] R. Biek, A. J. Drummond, and M. Poss, "A virus reveals population structure and demographic history of its carnivore host," Science, vol. 311, no. 5760, pp. 538-541, 2006.

[102] E. B. Carstens and L. A. Ball, "Ratification vote on taxonomic proposals to the International Committee on Taxonomy of Viruses (2008)," Archives of Virology, vol. 154, no. 7, pp. 1181-1188, 2009.

[103] C. J. Hartley, D. R. Greenwood, R. J. C. Gilbert et al., "Kelp fly virus: a novel group of insect picorna-like viruses as defined by genome sequence analysis and a distinctive virion structure," Journal of Virology, vol. 79, no. 21, pp. 1338513398, 2005.

[104] P. D. Scotti, J. F. Longworth, N. Plus, G. Croizier, and C. Reinganum, "The biology and ecology of strains of an insect small RNA virus complex," Advances in Virus Research, vol. 26, no. 1, pp. 117-143, 1981.

[105] P. D. Christian and P. D. Scotti, "The picorna-like viruses of insects," in The Insect Viruses, L. Miller and A. Ball, Eds., pp. 301-336, Plenum Press, New York, NY, USA, 1998.

[106] T. Manousis and N. F. Moore, "Cricket paralysis virus, a potential control agent for the olive fruit fly, Dacus oleae Gmel," Applied and Environmental Microbiology, vol. 53, no. 1, pp. 142-148, 1987.

[107] N. Plus and P. D. Scotti, "The biological properties of eight different isolates of cricket paralysis virus," Annales de l'Institut Pasteur Virologie, vol. 135, no. 3, pp. 257-268, 1984.

[108] G. Fedière, R. Philippe, J. C. Veyrunes, and P. Monsarrat, "Biological control of the oil palm pest Latoia viridissima (Lepidoptera, Limacodidae) in Cote d'Ivoire, by a new picornavirus," BioControl, vol. 35, no. 3, pp. 347-354, 1990.

[109] L. Kanga and G. Fediere, "Towards integrated control of Epicerura pergisea (Lepidoptera: Notodontidae), defoliator of Terminalia ivorensis and T. superba, in the Cote d'Ivoire," Forest Ecology and Management, vol. 39, no. 1, pp. 73-79, 1991.

[110] J. C. Boyer and A. L. Haenni, "Infectious transcripts and cDNA clones of RNA viruses," Virology, vol. 198, no. 2, pp. 415-426, 1994. 
[111] M. Benjeddou, N. Leat, and S. Davison, "Black queen-cell virus RNA is infectious in honey bee pupae," Journal of Invertebrate Pathology, vol. 81, no. 3, pp. 205-206, 2002.

[112] S. Boyapalle, R. J. Beckett, N. Pal, W. A. Miller, and B. C. Bonning, "Infectious genomic RNA of Rhopalosiphum padi virus transcribed in vitro from a full-length cDNA clone," $V i$ rology, vol. 375, no. 2, pp. 401-411, 2008.

[113] N. Pal, S. Boyapalle, R. Beckett, W. A. Miller, and B. C. Bonning, "A baculovirus-expressed dicistrovirus that is infectious to aphids," Journal of Virology, vol. 81, no. 17, pp. 9339-9345, 2007.

[114] D. M. Tufts, K. Spencer, W. B. Hunter, and B. Bextine, "Delivery system using sodium alginate virus loaded pellets to red imported fire ants (Solenopsis invicta, Hymenoptera: Formicidae)," The Florida Entomologist, vol. 94, no. 2, pp. 237-241, 2011. 

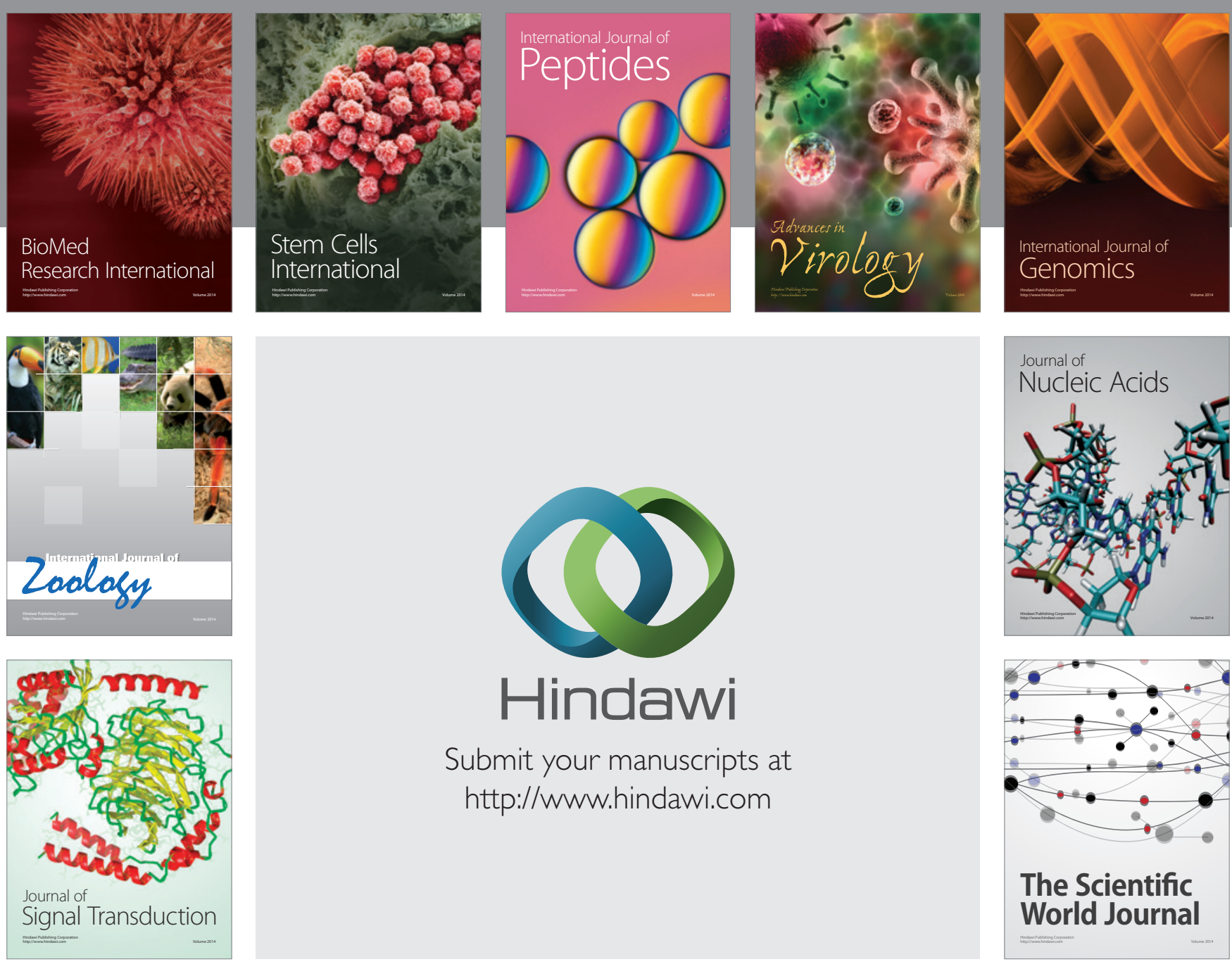

Submit your manuscripts at

http://www.hindawi.com
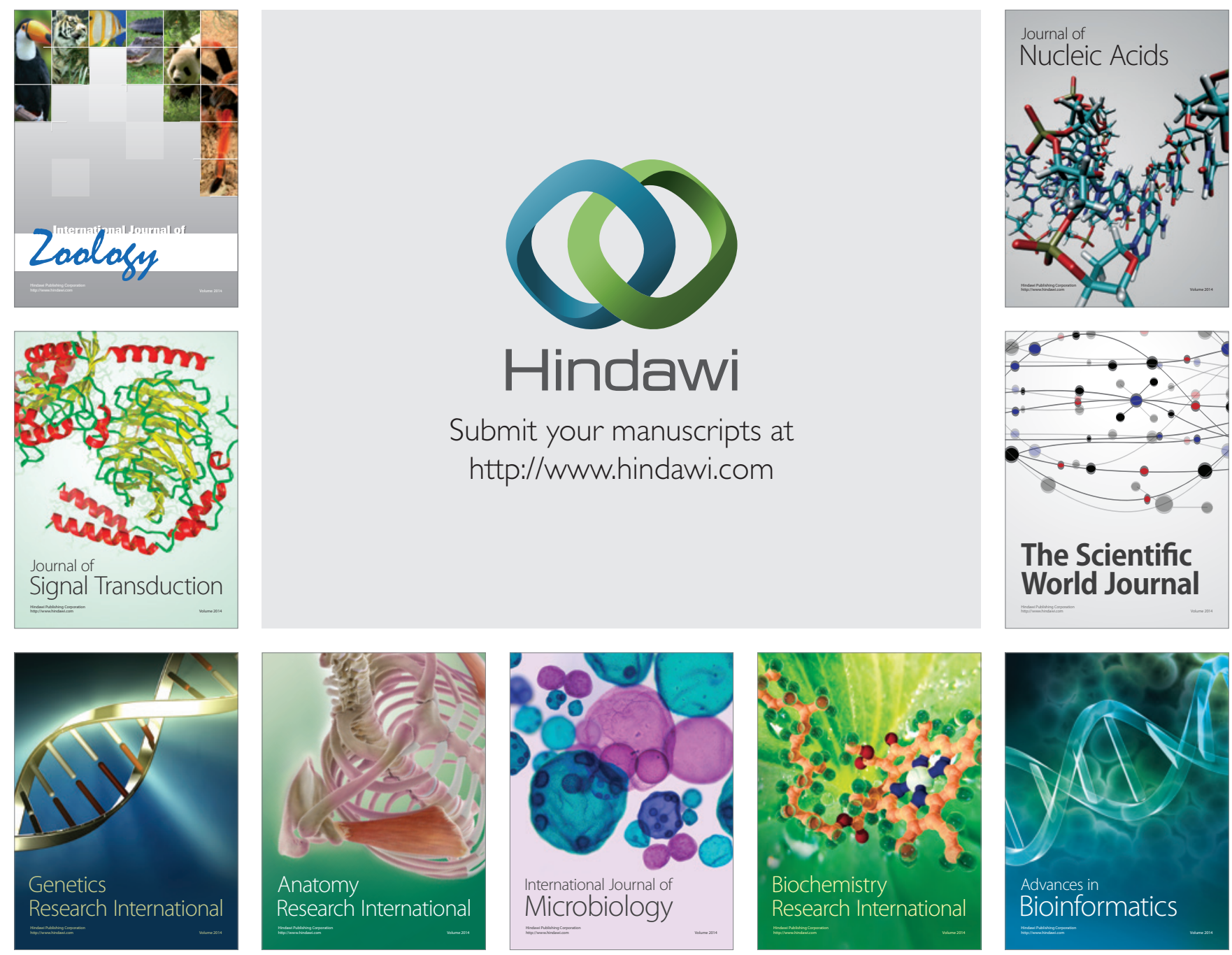

The Scientific World Journal
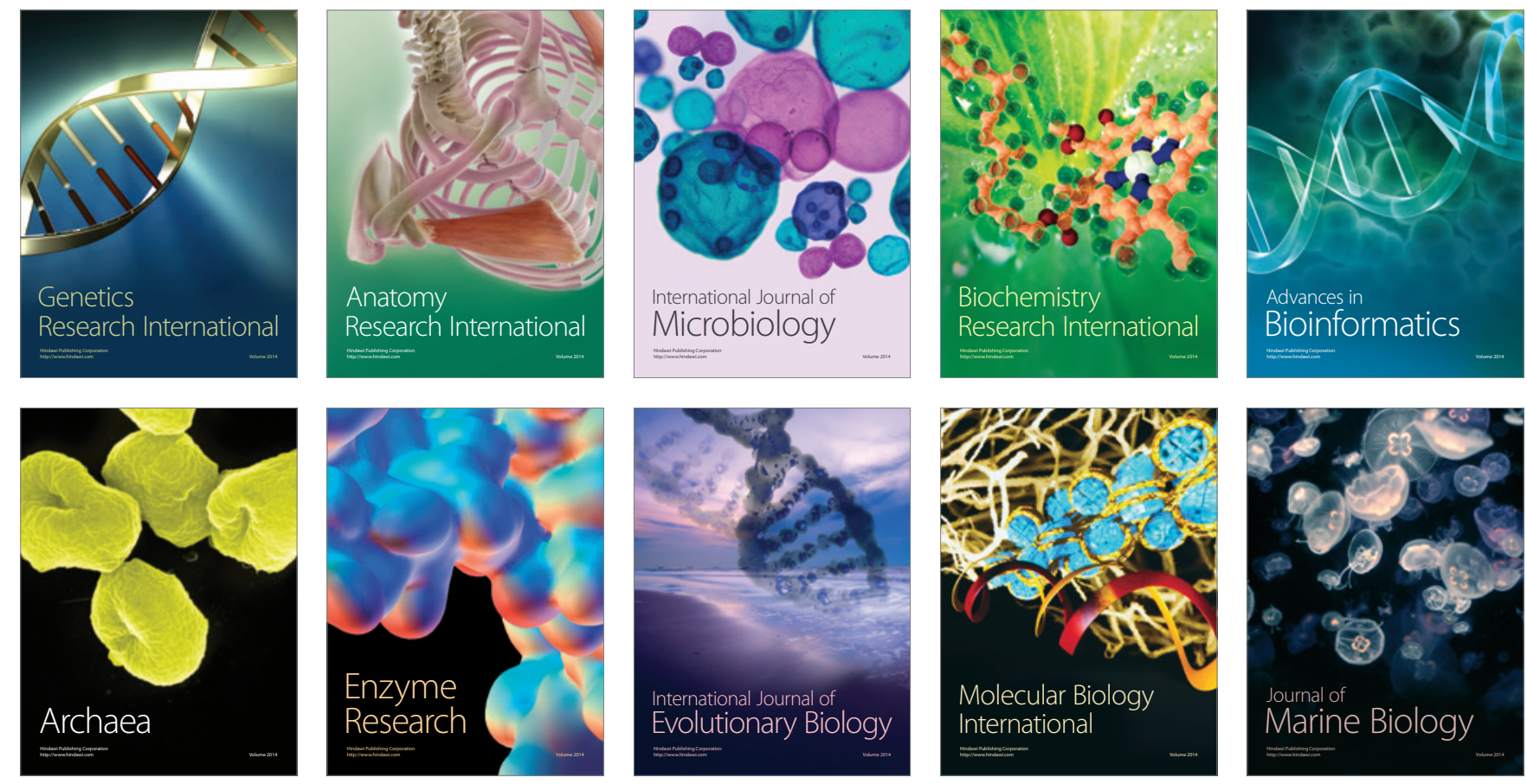